\title{
SANCTIONS FOR ILLEGAL CONDUCT WITH POISONOUS AND DRASTIC SUBSTANCES OR POISONOUS AND DRASTIC PHARMACEUTICAL DRUGS
}

\author{
Maryna Bondarenko \\ ${ }^{I}$ Postgraduate student, State Research Institute of the Ministry of Internal Affairs of Ukraine, assistant judge \\ of the Criminal Cassation Court within the Supreme Court, Kyiv, Ukraine, e-mail: bondms@ukr.net
}

\begin{abstract}
The article is devoted to the investigation of criminal legal norm, namely, to one of its parts - sanction. In this aspect, a brief overview of general theoretical problems is made, their importance and prospects in further study for science and practice are shown. The aim of the article: to analyze the general concept of criminal legal sanction, to investigate the sanctions of norms provided by Art. 321 of the CC of Ukraine, to identify the shortcomings of their design and to suggest ways of their improvement. The research methodology: historical-legal, comparative-legal, logical ones, the method of analysis and synthesis. The definition of the concept of sanction is described, as well as what types of sanctions exist, which prevail in the norms of the law of Ukraine on criminal liability, etc. In addition, the peculiarities of the sanction design, in particular in comparison with foreign criminal legislation, and the existing shortcomings in the domestic criminal law are provided. In total, this provided an opportunity to analyze Art. 321 of the Criminal Code of Ukraine (hereinafter - the CC of Ukraine), and to formulate ways to improve it. The main results: to apply the experience of foreign criminal law, which provides the gradation of even each type of punishment, the use of arithmetic rules to increase and decrease the amount of punishment in case of existence of mitigating or aggravating circumstances, etc., at least for the most common crimes.
\end{abstract}

Keywords: criminal law, criminal legal norm, punishment, sanction, design of sanction, relatively defined sanction, alternative sanction, cumulative sanction, fine, detention, corrective labor, imprisonment.

JEL Classification: K10, K14, K39, K42

Formulas: 0; fig.: 0; tabl.: 0; bibl.: 25.

Introduction. Sanction is a part of the criminal legal norm, which is often changed by the legislator and this fact causes a lot of discussions. Not only the fate of a convict depends on the punishment provided by the relevant sanction, but also the general idea of the crime, the severity, the proportionality of the punishment provided for the offense, the general preventive function of criminal law. Due to the sanction, it is possible to trace partially the direction of the criminal policy on the severity of punishment for certain types of crimes, etc. Thus, there is every reason to say that this area of research is always relevant.

Literature Review. The study is based on the analysis of scientific works of both domestic and foreign scholars, including references to monographs, scientific articles, scientific and practical commentaries on criminal law, as well as the provisions of the CC of Ukraine, in particular the studied Art. 321 of the CC of Ukraine. Foreign criminal law has been used.

Aims. To analyze the general concept of criminal legal sanction, to investigate the sanctions of norms provided by Art. 321 of the CC of Ukraine, to identify the shortcomings of their design and to suggest ways of their improvement.

Methods. In this study, various methods have been applied, including historicallegal, comparative-legal, logical ones, the method of analysis and synthesis. 
Results. The word sanction translated from Latin (sanctio) means inviolable law, the strictest resolution. Sanction is most often defined as a part of the article of the Special Part of the CC of Ukraine, which upon its content and severity reflects the nature and degree of public danger of relevant crime.

For a long time, the science of criminal law has developed many definitions of "sanction", which pay attention to various aspects, looking at the sanction not only as a part of the norm, since still this term is quite ambiguous.

It is impossible to give all the definitions, but it is also impossible to ignore the scientific developments of Oleg Leist, which had a determining influence on the development of the sanctions doctrine. He defined the sanction of a legal norm as a normative definition of compulsory measures applied in case of a crime commission, which contain its final legal assessment [10, p. 7].

Domestic scholar O. Soproniuk amongst the vast majority of definitions of the concept of a legal norm sanction identified the following essential features: 1) this is an element of a legal norm; 2) it acts as a way to protect a certain rule of conduct, enshrined in the disposition of a legal norm, from its possible violations, and in order to prevent their commission; 3) this is an indication of adverse consequences that occur in case of violation of a legal norm; 4) it is applied by the subjects authorized to bring to criminal liability [19, p. 238].

The structure of the criminal legal norm also includes hypothesis and disposition.

The very concept of three-element (three-chain) today is generally accepted in the science of criminal law, which is believed to have been proposed in the late first half of the twentieth century by Sergei Golunski and Mikhail Strogovich. According to this concept, the relationship of these three elements (hypothesis, disposition and sanction) is reduced to the formula "if..., then..., otherwise..." [24, p. 125].

And in relation to the above, the opinion of Yurii Zhytsinskii is mentioned, which has been expressed by this scholar about 40 years ago, relevant to this day, that without disposition the norm is unthinkable, without hypothesis - meaningless, without sanction - incapable [7, p. 44].

Though this three-element concept is currently often criticized, and it is not always possible to establish all three elements in a legal norm.

The Criminal Code of Ukraine provides sanctions for committing a certain criminal act only in the norms of the Special Part.

Thus, in the norms of the Special Part of the Criminal Code of Ukraine the hypothesis is usually not distinguished, it is common to all norms of this Special Part and is set out in Art. 2 of the General Part of this Code, which stipulates what should be considered the ground for criminal liability. Thus, this ground is acknowledged as the commission of an act that contains all the elements of a crime under the Criminal Code of Ukraine.

The application of sanctions is not the main core of the criminal legal norm, but a backup mechanism for ensuring law and order. Since the requirement to impose liability on a person guilty of the crime is derived from the requirement of the norm (rules of conduct, disposition) [18, p. 65-66]. 
Sanction provides punishment for the socially dangerous act, the statement of which is contained in the disposition. According to the punishment noted in the sanction, crimes are distinguished pursuant to the degree of public danger.

A punishment provided by the sanction must be fair, adequate and proportionate to the offense, so that it is commensurate with the act set out in the disposition, at the same time so as not to cause abuse of judicial discretion.

In this respect, the opinions of scholar Yurii Filei regarding the general preventive effect of criminal legal sanctions are valid. The effect of general prevention arises from the interaction between sanctions and their application in specific cases. He believes that the mechanism of preventive effect of a sanction on the public consciousness is carried out due to the so-called threat of sentencing before the commission of a criminal act, namely in the form of individual penalty imposition by a court. The preventive effect is also carried out in the form of execution of this punishment [21, p. 389-390].

Therefore, while agreeing with the above, it should be noted that in case of partial or complete non-application of a sanction, it can be asserted that it undermines the general preventive function of criminal legal sanctions and generally weakens the preventive effect of criminal law.

The effectiveness of a sanction is determined accordingly by its correct application in judicial practice, if the courts do not consider it necessary, so to speak, to overcome it.

Thus, if courts often resort to Art. 75 of the Criminal Code of Ukraine, which provides the release of a convict from serving a probation sentence, or Art. 69 of the $\mathrm{CC}$ of Ukraine, according to which a sentence below the lowest limit can be imposed, or judges may decide to move to another type of punishment, not specified in the sanction of the article, the conclusion about the effectiveness of the sanction is obvious.

Domestic scientist Oleksii Horokh conducted a detailed analysis of the existing problems of designing sanctions of criminal legal norms. Amongst ten scientific works, he singled out nine most common shortcomings in designing sanctions of norms from the Special Part of the Criminal Code of Ukraine, in particular, such as a certain inconsistency in determining the types of penalties, in other words, the deviation from the general rule on designing sanctions (according to which penalties range from less to more severe); inexpediency of specifying the minimum limit of punishment in the sanction of the article, which is already established in the General Part of the CC of Ukraine; the equivocacy of predictability of a significant number of basic punishments for the same crime in the article sanction (because in some cases this number reaches five types), etc. Accordingly, this scientist proposed eight basic rules for designing sanctions of special criminal legal norms, namely how the sanction should change with increasing degree of public danger of the act, the proportionality of the predictability of the main punishment together with additional ones and others [5].

It is impossible to ignore the opinion of scholar Yevheniia Vecherova as for the fact that the imperfection of the criminal legal sanctions design at the level of law 
enforcement can cause the following problems: 1) the problem of artificial alternatives; 2) the right to the existence of mandatory sanctions; 3 ) the problem of differences in the definition of minimum and maximum limits of the sanction (in the situation of a large gap between the minimum and maximum limit) [4, p. 65].

Regarding the sanction design in the CC of Ukraine, the following aspect should also be highlighted. In the science of criminal law, discussions have been going on for a long time - does criminal law punish certain criminal acts or the subject of criminal liability, who has committed them?

Yes, indeed, bringing a person to criminal liability begins with the commission of a socially dangerous act by him/her that is recognized as a crime. Criminal liability is realized through individualized punishment of the guilty person for the act he/she has committed. Thus, the commission of a certain crime results in applying the sanction of the criminal law to a certain criminal, and first of all the gravity of the committed determines the punishment severity.

Regarding the above, it is worth mentioning the statement of the famous scholar Franz von Liszt that an act and a figure are not two opposites, as fatal legal delusion suggests, and an act belongs to a figure... We are asked: what is the consequence of a theft, instead of asking, what does the thief deserve? It is not the concept that is punished, but the figure, therefore the measure of punishment should be determined not according to the concept, but to the act of the figure. That is perfectly understandable, and in the meantime, it is still considered heresy [11, p. 58-59].

Herewith, it should be noted that it is clear why discussions continue on what is punishable first - the act or the offender, as it is due to the construction of the norms of the Special Part of the Criminal Code of Ukraine, because the emphasis in the norm is put on the act.

Thus, the disposition of any article of the Special Part of the Criminal Code of Ukraine, as a rule, begins with the name of a crime or list of illegal actions (for example, "High treason..." Part 1 of Article 111 of the CC of Ukraine, "Murder, that is willful unlawful causing death of another person" Part 1 of Article 115 of the CC of Ukraine, "A covert stealing of somebody else's property (theft)" Part 1 of Article 185 of the CC of Ukraine, or as in Part 1 of Article 321 of the CC of Ukraine "Illegal production, making, purchasing...").

Therefore, before describing the sanction of the article, there must be an irrespective and impersonal "shall be punishable".

Thus, with such a construction of the norm, it is seen that the criminal law punishes the act.

But this feature of the construction of criminal law norms is generally not typical for the criminal codes of other countries, for example, European countries:

- in the Criminal Code of the Republic of Lithuania, the disposition of the article begins with the words "A person who... shall be punished" or immediately with the title of the position held by the perpetrator;

- in the Criminal Code of the Republic of Poland "Whoever, ... shall be subject to the penalty" or "If the perpetrator... shall be subject to the penalty";

- in the Criminal Code of the Republic of Bulgaria "A person who commits 
violence ... shall be punished" or "A person who is obliged ... shall be punished", etc.

As for the types of sanctions, domestic scholars suggest using the division of sanctions, which, depending on the existence or lack of additional penalties, may be simple and cumulative; according to the number of main types of punishments single and alternative; according to the punishment choice for the court - absolutely defined and relatively defined [14, p. 80].

The Criminal Code of Ukraine currently uses three types of sanctions alternative, relatively defined and cumulative ones.

To find out how these sanctions differ, it is necessary to use the definitions provided by Viacheslav Borysov. He defines each of these sanctions as follows:

- a sanction that indicates one type of punishment and defines its limits is relatively defined. The Criminal Code of Ukraine applies its two types: a sanction, which defines both the minimum and maximum limits of the same type of punishment and a sanction, which specifies only the maximum limit of punishment;

- an alternative sanction states two or more types of basic punishments, amongst which the court chooses only one. It is believed that such a sanction gives the court wider opportunities to choose the necessary punishment, more individually determined;

- in a cumulative sanction, in addition to the main punishment, relatively defined or alternative sanctions may contain an indication of one or more additional punishments of a certain type, which may be imposed by the court as additional to the main one. The additional punishment can be absolutely certain or relatively certain. Additional penalties are specified in the sanctions either as mandatory or optional. In the latter case, depending on the circumstances of the case, the court decides on the application or non-application of this punishment [3, p. 871-872].

Sanctions are also divided into coercive and incentive ones.

At the same time, the analyzed Article 321 of the Criminal Code of Ukraine provides these two types of sanctions, coercive ones are enshrined in parts 1-4. Part 5 of this article regulates a special type of a person's release from criminal liability, in other words criminal liability is not realized, and the punishment is not applied.

Pursuant to Article 321 of the Criminal Code of Ukraine the illegal conduct with poisonous and drastic substances or poisonous and drastic pharmaceutical drugs shall be punishable.

However, for clarity, it is not superfluous to quote the content of the article under study, the sanctions of which will be further considered.

"Article 321. Illegal production, making, purchasing, transportation, sending, storage for selling purposes, or sale of poisonous and drastic substances or poisonous and drastic pharmaceutical drugs

1. Illegal production, making, purchasing, transportation, sending, storage for selling purposes, or sale of poisonous and drastic substances, other than narcotics, psychotropic substances or their analogues, or poisonous and drastic pharmaceutical drugs and also any such actions in regard of any equipment devised for the production or making of poisonous and drastic substances or poisonous and drastic 
pharmaceutical drugs, where these actions were not duly authorized, -

shall be punishable by a fine from one thousand up to four thousand tax-free minimum incomes, or detention for a term of three to six months, or imprisonment for a term up to three years.

2. Violation of rules related to production, making, purchasing, storage, dispensation, inventorying, transportation or sending of poisonous and drastic substances, other than narcotics, psychotropic substances or their analogues, or poisonous and drastic pharmaceutical drugs, -

shall be punishable by a fine from one thousand up to four thousand tax-free minimum incomes, or detention for a term of three to six months, or imprisonment for a term up to three years.

3. Acts provided in Parts 1 and 2 of this Article, if committed repeatedly, or by a group of persons upon their prior conspiracy, or if subject of such actions were poisonous and drastic substances which are not being narcotic or psychotropic substances or their analogues, or poisonous and drastic pharmaceutical drugs in large quantities, -

shall be punishable by imprisonment for a term of three to five years.

4. Acts provided for in Parts 1 and 2 of this Article, if committed by an organized group of persons, or if subject of such actions were poisonous and drastic substances which are not being narcotics or psychotropic substances or their analogues, or poisonous and drastic pharmaceutical drugs in especially large quantities,-

shall be punishable by imprisonment for a term of five to ten years".

By the way, the frequent variability of sanctions depending on the legislator's will should be remarked. Thus, the sanctions of Parts 1 and 2 of the studied Art. 321 of the Criminal Code of Ukraine were last amended on the grounds of the Law of Ukraine No. 2617-VIII of November 22, 2018, which entered into force on July 1, 2020 , in terms of increasing the fine previously determined within 50 to 100 tax-free minimum incomes, and currently - from $1000(\times 17 \mathrm{UAH})$ to 4000 tax-free minimum incomes.

Thus, the sanctions established by paragraphs $1-4$ generally provide three types of punishment: a fine, detention, and imprisonment, herewith the latter punishment is provided in parts 3-4 as mandatory.

According to part 1 of Art. 321 of the Criminal Code of Ukraine, illegal actions with poisonous/drastic substances or pharmaceutical drugs are punishable by: 1) a fine from one thousand to four thousand tax-free minimum incomes, or 2) detention from three to six months, or 3) imprisonment for up to three years (in the latest version of the Law No. 2617-VIII of November 22, 2018, which entered into force on July 1, 2020).

Thus, the noted sanction testifies that this crime, according to the classification of criminal offenses, is referred to minor offences (Article 12 of the Criminal Code of Ukraine in the latest version of the Law of Ukraine No. 2617-VIII of November 22, 2018, which entered into force on July 1, 2020).

It should also be noted that the criminal law of Ukraine in comparison with the 
criminal law of foreign countries provides one of the most extensive punishment systems, which provides 12 types of penalty.

These penalties are fixed in Art. 51 of the Criminal Code of Ukraine on the principle from the least severe to the most severe.

However, in accordance with the gradation of the analyzed alternative punishments under Part 1 of Art. 321 of the Criminal Code of Ukraine, taking into account their severity, they occupy: the first (fine), eighth (detention) and eleventh (imprisonment) steps.

That is, "on the way" of the formation of sanctions under Part 1 of Art. 321 of the Criminal Code of Ukraine - from a fine to detention, the legislator had the opportunity to provide a number of punishments, namely: community service, corrective labor; from detention to imprisonment there is also a reserve - the possibility of imposing custodial restraint (we think, of course, also taking into account the amendments made to the law - de lege ferenda).

The fine is a monetary penalty. It can be imposed both as the main punishment, and as an additional one. It does not have any exceptions, i.e. it can be assigned to all subjects of the crime, including minors. In the analyzed sanction of Part 1 of Art. 321 of the Criminal Code of Ukraine, the fine was actually set at a minimum, as its lower limit was set at 30 tax-free minimum incomes. After the latest amendments to the abovementioned Law No. 2617-VIII, the amount of the fine was significantly increased; we consider it to be a positive trend. Currently, the lower limit of the fine under Part 1 of this article is 1000 tax-free minimum incomes, which is 17000 $\mathrm{UAH}$.

However, it can be stated that, in general, the fine, unfortunately, is not so often applied in judicial practice. The above also relates to the imposition of this punishment under Part 1 of Art. 321 of the Criminal Code of Ukraine. This is due, in particular, to the complicated economic situation in the country, unemployment and so on.

But this is not a reason to abandon this type of punishment, choosing one of the most severe - imprisonment, only because of the difficult financial situation of the perpetrator.

In this regard, it would be important to develop and implement at the legislative level a mechanism for installment payment of fines and under certain conditions, for example, when the convict begins to mend his/her ways (changes the residence, registers at the office of expert in narcology and mental physician, acquires another specialty, becomes engaged in socially beneficial activities, etc.), not to oblige him/her to pay the full amount of the fine imposed by the court.

A similar situation applies to the imposition of such a type of punishment as detention. Among the reasons for the infrequent use of the latter type of punishment in Ukraine, there are problems with the execution of such sentences (a proper system of detention facilities has not been established yet).

According to Part 2 of Art. 321 of the Criminal Code of Ukraine illegal actions with poisonous/drastic substances or pharmaceutical drugs shall be punishable by a fine from one thousand (17 $000 \mathrm{UAH})$ up to four thousand (68 $000 \mathrm{UAH})$ tax-free 
minimum incomes, or detention for a term of three to six months, or imprisonment for a period of up to three years (in the latest version of Law No. 2617-VIII of November 22, 2018, which entered into force on July 1, 2020).

The crime noted in Part 2 of Art. 321 of the Criminal Code of Ukraine, is mostly committed by special entities (bearing in mind pharmaceutical and health professionals). At the same time, qualified and especially qualified corpus delicti provide liability for the actions provided in Part 2 of Art. 321 of the Criminal Code of Ukraine, so the legislative decision to supplement the sanctions of Parts 2-4 of Article 321 of the Criminal Code of Ukraine with such a punishment as deprivation of the right to hold certain positions or to be engaged in certain activities (in Part 2 - one of the main types of punishment, in Parts 3-4 - as an additional one) is completely justified.

Finally, it will be effective for law enforcement, particularly under Part 2 of Art. 321 of the CC of Ukraine, not only to remove the perpetrator from office or to deprive him/her from the right to be engaged in certain activities related to the committed crime, but also, adhering to the principle of saving criminal repression, to extend punishments in the form of monetary redress - fines and corrective labor.

In the science of criminal law of Ukraine it is rightly suggested to the legislator, when designing sanctions in norms with qualifying and especially qualifying features, to apply one of schemes of transition from the sanction of the norm providing the basic corpus delicti to the sanction of the norm describing a qualified corpus delicti: a) not to change either types, or number of alternatively provided types of punishment, but to increase proportionally their amounts; b) not to change the number of alternatively defined types of punishment, but to reduce the number of milder types of punishment and, at the same time, to increase the number of more severe types of punishment; c) to move gradually from the most alternative sanction to the least alternative or completely mandatory one by means of reducing the number of lenient types of punishments [8, p. 212].

However, when designing the sanction of Part 3 of Art. 321 of the Criminal Code of Ukraine, which provides a qualified corpus delicti in comparison with Parts 1 and 2 of this article, i.e. increased degree of public danger of the act provided in it, the gradual increase in the sanction is not observed.

The disposition of Part 3 of Art. 321 of the Criminal Code of Ukraine contains three qualifying features - the commission of a crime "repeatedly" or "by a group of persons upon their prior conspiracy", or if the subject of criminal acts was represented by poisonous/drastic substances or pharmaceutical drugs "in large quantities".

Instead, the sanction is relatively specified, but it has not changed very proportionally in comparison with the basic corpus delicti, as it provides only one type of punishment, namely imprisonment for a term of three to five years.

The situation is similar, when the legislator designs a sanction for an especially qualified corpus delicti. The disposition of Part 4 of Art. 321 of the Criminal Code of Ukraine provides especially qualifying features - commission of this crime by an "organized group" or, if the subject of criminal actions was represented by 
poisonous/drastic substances or pharmaceutical drugs, "in especially large quantities". The sanction is also relatively specified and provides only one type of punishment in the form of imprisonment, but for a longer term - of five to ten years.

Discussion. It is believed that the design of sanctions in articles is debatable and devoid of any universal solution [16, p. 96]; in the opinion of scholar Viacheslav Navrotskyi, proposals to determine the limits of sanctions usually have emotional coloring [15, p. 8]; scholar Mykola Melnyk notes that proposals as for determining the punishment for a particular type of crime are based mainly on the subjective vision of the author [13, p. 18].

I support the opinion of domestic scholars Anatolii Muzyka and Oleksii Horokh, according to which it is hardly possible to completely avoid the subjective moment while establishing sanctions of criminal legal norms in the law [14, p. 78].

Certainly, it is impossible to completely rule out the existence of a subjective vision while creating sanctions, but this does not mean that it is irrelevant to think about the introduction of standard sanctions.

Conclusion. The introduction of standard sanctions for Ukraine is a rather promising trend, quite relevant and necessary, given the repressive nature of the penalties prevailing in the criminal law of Ukraine. As a result, this results in a possible abuse of judicial discretion, which negatively affects public opinion reflecting trust in the judiciary.

It would also be useful to apply the experience of foreign criminal law, which provides the gradation of even each type of punishment, the use of arithmetic rules to increase and decrease the amount of punishment in case of existence of mitigating or aggravating circumstances, etc., at least for the most common crimes.

\section{References:}

1. Alieksieieva, N. (2017), "Sanctions in articles on crimes against justice committed by or in relation to witnesses, experts, translators", Scientific Journal of the National Academy of the Public Prosecutor's Office, №1, pp. 11-22.

2. Berylo, O. (2019), "Problems of bringing to liability for failure to provide a sick person with care by a health professional", Scientific Bulletin of Uzhhorod National University. Law Series, edition 57, vcolume 2, pp. 57-60.

3. Tatsii, V. and others (2016), The Big Ukrainian Legal Encyclopedia: in 20 v. / National Academy of Legal Sciences of Ukraine; V. M. Koretsky Institute of State and Law of the National Academy of Sciences of Ukraine; Yaroslav Mudryi National Law University. Kharkiv: Pravo, 1064 p.

4. Vecherova, Ye. (2015), "Criminal legal sanctions through the prism of the main vectors of contemporary criminal policy of Ukraine (critical analysis of some novelties of the Criminal Code of Ukraine)", Scientific Bulletin of the International Humanitarian University. Series: Jurisprudence, volume 2, №13, pp. 64-66.

5. Horokh, O. (2009), "Problems of designing sanctions of special criminal law norms", Scientific notes of the National University of "Kyiv-Mohyla Academy", v. 90, pp. 94-98.

6. Denysova, T. and Filei, Yu. (2008), Criminal legal sanctions and their application for crimes against property, Center for Educational Literature, $176 \mathrm{p}$.

7. Zhytsinskii, Yu. (1968), Sanction of a norm of Soviet civil law, Publishing office of Voronezh University, Voronezh, $123 \mathrm{p}$.

8. Kalmykov, D. (2012), "Analysis of sanctions of Article 150 of the Criminal Code of Ukraine", Bulletin of the National Academy of the Public Prosecutor's Office of Ukraine, №4, pp. 37-42.

9. Knyzhenko, O. (2005), "Influence of qualifying sanctions on the limit of criminal legal sanction", Law and security, №4, pp. 73-75.

10. Leist, O. (1962), Sanctions in Soviet law, Gosyurizdat, Moscow, 238 p.

11. Liszt, F. (1895), Punishment and its purposes, Publishing house Dresdesa, Saint Petersburg, 280 p.

12. Lutsyk, H. (2011), "Sanctions in the system of criminal legal means of protection of human labor rights", 
Scientific Bulletin of Lviv State University of Internal Affairs. Legal series, №1 (2), pp. 181-191.

13. Melnyk, M. (2003), "Legislative trends to upgrade the new Criminal Code of Ukraine", Code of Ukraine of 2001 (problems, prospects and ways to upgrade criminal law), materials of international scientific practical conference, LIVS, Lviv, pp. 16-19.

14. Muzyka, A. and Horokh, O. (2012), Punishment and its application for crimes against public health, Kyiv, $404 \mathrm{p}$.

15. Navrotskyi, V. (2001), Continuity of the criminal legislation of Ukraine (comparative analysis of the Criminal Codes of Ukraine of 1960 and 2000), Atika, Kyiv, 272 p.

16. Yatsenk, S. (2002), Scientific and practical commentary to the Criminal Code of Ukraine: upon the state of legislation and resolutions of the Plenum of the Supreme Court of Ukraine, A.C.K, Kyiv, 936 p.

17. Osadchyi, V. (2004), "Sanctions in special criminal legal norms", State and Regions: Series and Law, №1, pp. 52-54.

18. Prokhorov, V. (1984), Crime and liability. Leningrad. Publishing office of Leningrad University, 135 p.

19. Soproniuk, O. (2016), "The concept of sanction in the theory of law", Historical and Legal Journal, №1

(7), pp. 234-239.

20. Fedchyshyn, Yu. (2018), "Problems of designing sanctions of criminal legal norms, establishing liability for abuse of power or official authority by a law enforcement officer", International Scientific Journal

"Internauka". Series: "Juridical Sciences", №4, pp. 30-38. URL: https://www.internauka.com/issues/law2018/4/3896/.

21. Filei, Yu. (2017), "Preventive effect of criminal legal sanctions", Transcarpathian legal readings. Series VI. Criminal law and criminology, criminal executive law, volume 1, pp. 388-393. URL: https://dspace.uzhnu.edu.ua/jspui/bitstream/lib/14937/1/\%D0\%97\%D0\%90\%D0\%9F\%D0\%9E\%D0\%91\%D 0\%86\%D0\%96\%D0\%9D\%D0\%98\%D0\%99\%20\%D0\%92\%D0\%9F\%D0\%9B\%D0\%98\%D0\%92.pdf.

22. Filei, Yu. (2006), Criminal legal sanctions for crimes against property: extended abstract of dissertation to obtain the scientific degree of PhD in Law, Kyiv, $19 \mathrm{p}$.

23. Filei, Yu. (2003), "The concept of criminal law sanctions", Bulletin of the prosecutor's office, №11, pp. 30-35.

24. Shevchenko, Ye. (2012), "On the issue of the criminal legal norm structure", Problems of legality, Issue. 118 , pp. 125-133.

25. Shemshuchenko, Yu. (2003), Juridical encyclopedia: in 6 v., Ukraine encycl., Kyiv, V. 5,736 p.

Received: August 04, 2020

Approved: September 10, 2020 